\title{
LEGAL ASPECTS OF HEALTH PROTECTION FOR FARMERS IN THE PRODUCTION OF ALIMENTARY RAW MATERIALS IN POLAND. HARMFUL CHEMICAL FACTORS
}

\author{
Czapka M.1,2, Jochymczyk A.3
}

\section{'Cardinal August Hlond University of Education, Myslowice}

\section{Opole University of Technology, Opole}

\section{University of Economics and Administration, Bytom}

In the process of performing their job, farmers are exposed to numerous factors that are harmful to the health. First of all, the harm caused by chemical and biological factors, and to a lesser extent, physical ones. The long-term injurious effects of chemical agents on farmers can lead to the development of occupational diseases. Therefore, the article focuses on the legal regulations concerning health protection for farmers against these factors and, more particularly, on the laws directly related to farm work.

Key words: occupational hygiene, occupational diseases in agriculture, harmful chemical agents, legislation concerning occupational health and safety

\section{Introduction}

Despite the development of new technologies, agriculture continues to play a very important role, as it provides food for six billion people. It is true that nowadays the work of farmers is undervalued in public opinion. However, this does not change the fact that without farmers, other social groups would have no chance at survival. Therefore, in spite of the fact that farmers are devalued in the social hierarchy, it is important to provide them with adequate health and life protection. It should be noted that the health of farmers has a direct impact on the socio-economic situation of their families.

The structure of occupational diseases in agriculture is presented below. The question of occupational diseases in agriculture is regulated by different laws than those concerning other professional groups. It should be noted, however, that the list of occupational diseases is defined by the universally binding regulations issued under the Labour Code [1]. The definition of an occupational disease in agriculture is defined by the Farmers' Social Security Act [2]. Provisions of this act define the notion of what an occupational disease in agriculture is. Accordingly, an occupational disease in agriculture is considered to be a disease that resulted in connection with work on the farm, and if this disease is included on the list of occupational diseases specified in the regulations issued on the basis of the Labour Code. The graph below presents the dynamics of occupational diseases in the evolution of agriculture. It shows that despite introducing a number of preventive measures in the realm of protecting farmers, the number of occupational diseases in agriculture in Poland is increasing.

By law, farmers are entitled to a one-time compensation payment on account of an occupational disease. As shown in graph 2, the highest one-time compensation payments were given to farmers on account of infectious diseases.

The diagram below presents the structure of health impairments among farmers caused by occupational diseases.

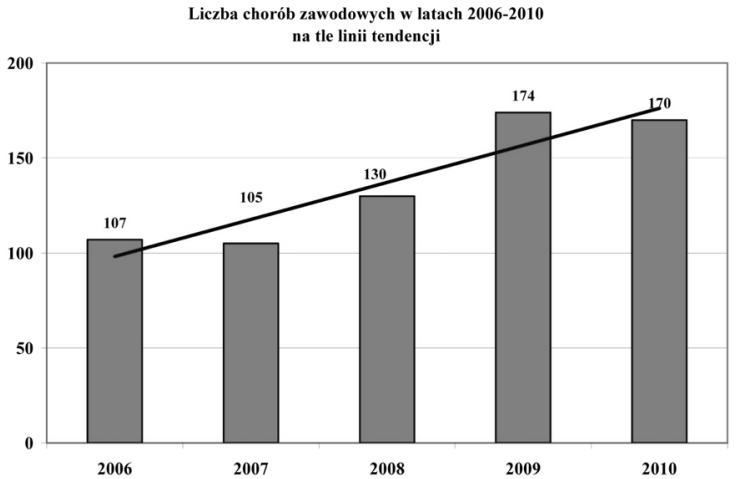

Graph. 1. Dynamics of the evolution of occupational diseases in agriculture in the years 2006-2010.

Source: Agricultural Social Security Fund 


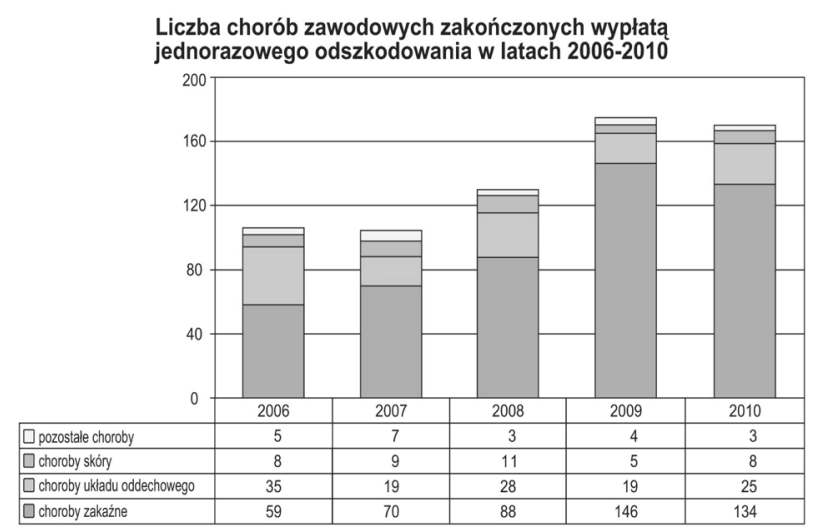

Graph. 2. Amount of occupational diseases terminated by a single one-time compensation payment in the years 2006-2010.

Source: Agricultural Social Security Fund. In yellow - other diseases, green - skin diseases, blue - respiratory diseases, red - infectious diseases.

The increase in the number of cases of occupational diseases amongst farmers and their impact on the substantial health impairments of this group require the implementation and monitoring of preventive measures. One such activity is to introduce new legislative solutions in the area of occupational health in agriculture. It should be noted, however, that farmers' health is also affected by the regulations governing the functioning of veterinary inspection and other public institutions and government agencies. For this reason, the aforementioned legal preventive measures can be divided into direct and indirect ones. The direct ones are associated with the processes of farming. The biggest health threat for the farmer comes from noxious chemical agents present in plant protection products, otherwise known as pesticides or health protection products. Chemical substances which have toxic, irritating or allergenic effects are the most common in the workplace in the form of aerosols, liquids, smoke, vapors and gases. They can cause acute, usually temporary, or chronic and often irreversible intoxications. Some of them may cause inflammatory reactions and allergic respiratory diseases [3]. Toxic chemicals can induce acute or chronic effects. As it is indicated acute toxicity is defined as harmful effects occurring within a relatively short period of time after administering a single dose or multiple doses within 24 hours' [4]. On the other hand, as it is underlined «in the case of chronic toxicity, we are dealing with the effects of long-term exposure to low doses, occurring in an industrial environment or habitat (air, water or food contamination)» [3]. In addition, the effects can be divided into local and organ-related as well as primary and secondary ones. As for local effects, they occur in the place of contact between the substance and the body. Then, the effects on organs occur in tissues and organs. Secondary effects are a consequence of the primary ones and «are a phenomenon frequently observed in toxicology studies and in some cases may even mask primary effects, making the interpreting of the results of this type of research difficult» [4].

\section{Direct preventive measures for the health protection of farmers in legislation}

In Poland, occupational health and safety is regulated by general and specific laws. The problem of health protection for farmers is primarily related to the fact that they perform their activities on so-called individual agricultural holdings (farms). This means that the farmers' family members are also employed in the production of alimentary raw materials, however, they are not employees under the law. By consequence, they are excluded from the jurisdiction of the authorities responsible for observing occupational health and safety regulations related to worker health protection, because under the law the employer is the person responsible for health and safety on the work site. Moreover, if a farmer does not hire employees, he is not an employer. However, there are some laws that are directed at the farmers themselves. These regulations can be defined as direct legal preventive actions. This legislation includes three key laws: the Decree of the Minister of Agriculture and Rural Development of January 12th, 1998 on the health and

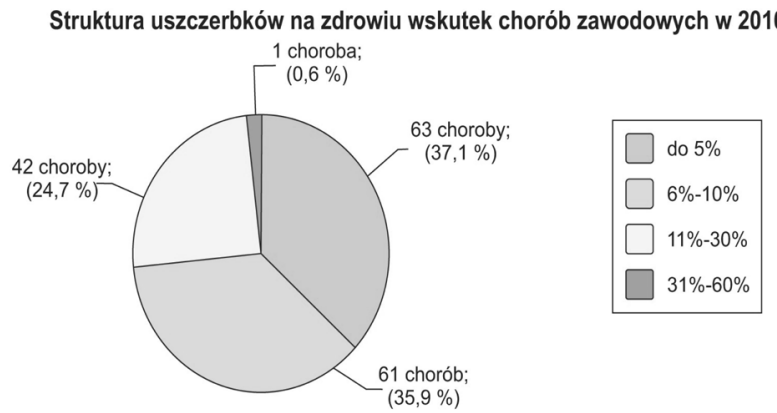

Graph. 3. Structure of health impairments among farmers due to occupational diseases in 2011.

Source: Agricultural Social Security Fund. 
safety of operating tractors, machinery, tools and technical equipment used in agriculture [5]; the Decree of the Minister of Agriculture and Rural Development of September 28th, 2001 on the health and safety of handling livestock [6]; and the Decree of the Minister of Agriculture and Rural Development of June, 24th 2002 on the health and safety of the use and storage of plant protection products and mineral and organic-mineral fertilizers [7]. The rules of hygiene in the workplace related to the mechanization of agriculture can be specified based on the first aforementioned regulation. As set by paragraph $1 \S$ 13 of the decree, heating and lighting system installations outside the cabin of machinery is compulsory. This ensures appropriate working conditions at night. In agricultural activities, the protection of farmers and bystanders against various types of harmful chemical agents is crucial. Therefore, it is forbidden, in accordance with the provisions of the decree, to turn on the devices indoors, in rooms which are not equipped with a system that evacuates exhaust gas outside. The injurious effects of exhaust gas on human health and its long-term negative effects are well-known. A farmer's lack of imagination while using machinery and equipment can result in serious health consequences for both him and bystanders. Therefore, in accordance with the provisions of this regulation, performing work with a tractor-mounted fertilizer spreader with a stirrer, is prohibited if it is done in the presence of bystanders. The distance at which the public is allowed to stand depends on the type of fertilizer.

Another principle of farmers' health at work is defined in the second decree. As set by $\S 5$ of this decree, while preparing and using chemical decontaminants and disinfectants in inventory rooms, manufacturers instructions must be observed and appropriate personal protective equipment must be used.

In the two previous decrees the legislation focused on the protection of farmers against accidents. However, not much attention was paid to the questions related to the occupational health of farmers and more particularly their protection against harmful chemical agents. Notwithstanding, this is justified by the specificity of these two areas of agricultural work. More attention was paid to harmful biological agents, but these will be addressed more closely in the next article on the health protection of farmers. The hygiene rules for farmers as they relate to exposure to harmful chemical agents are regulated most widely in the third decree, which also concerns health and safety at work as regards the use and storage of plant protection products as well as mineral and organic-mineral fertilizers. According to $\$ 2$ of the decree, workers undertaking tasks involved with the use and storage of plant protection products or fertilizers must be informed of:

1) the methods of protection against risks arising from the use and storage of plant protection products and fertilizers, and the impact of harmful factors on people's health or life;

2 ) the place, time and methods of using and storing plant protection products;

3 ) the contents of first aid kits;

4) the ways of administering first aid in case of poisoning;

5 ) the place and methods of water abstraction into the sprayer tanks or fertilizer spreaders;

6 ) the types of plant protection products used by employees with indication of their toxicity;

7) the requirements for the types of personal protective equipment and their proper usage;

8 ) the way of dealing with unused plant protection products and fertilizers, spray drifts and empty packaging;

9) the methods of washing and cleaning vehicles and equipment after use;

10) the way of proceeding in the case of a threat to human life or health as well as in the case of a threat to the environment;

11 ) and the methods of storage and transport of plant protection products and fertilizers.

Legislation requires that eating, drinking and smoking during breaks at work is allowed only after the worker removes his external personal protective equipment and after washing his hands and face and rinses his mouth with water that meets the requirements of potable water. It is required that the place designed for eating and smoking is to be no less than 50 meters away and downwind from the place where pesticides or fertilizers are being used. After work, the worker must wash his entire body with soap and warm water and rinse his mouth several times with water meeting the requirements for the drinking water. $\{0\}$ It is inadmissible that:

1) an employee uses plant protection products classified as toxic or very toxic;

2 ) an employee washes the underwear and clothing contaminated with plant protection products on their own. 
The information about the pesticide being used, its toxicity and duration of prevention for people, as well as the prohibition of any unauthorized access and of any person not wearing the appropriate personal protective equipment must be displayed at the front door of the closed rooms designed for plant production where pesticides are being used. After use, the unused plants protection product and remaining packages must be returned immediately to a warehouse designed for plant protection products and fertilizer storage. On the external doors of the warehouse these words are to be displayed:

1) «PLANT PROTECTION PRODUCTS AND FERTILIZER WAREHOUSE» or

2) «PLANT PROTECTION PRODUCTS WAREHOUSE», or

3) «FERTILIZER WAREHOUSE».

In accordance with the regulations of this decree, the warehouse must be equipped with:

1) a ventilation system:

a) which includes an emergency ventilation system - activated from outside and inside of the warehouse, ensuring at least ten air changes per hour;

b) which is continuous - activated from outside the warehouse, an hour before work, ensuring at least three air changes per hour;

2) windows with solar control glass;

3) an electrical, gas-tight and dust-proof system;

4) a separate septic sewage system, equipped with devices neutralizing the generated wastes;

5 ) personal protective equipment, depending on the risks involved;

6) medical kits including first aid equipment designed to contend with intoxication by plant protection products and fertilizers.

In addition the following are to be placed in a visible place in the warehouse:

1) a list of the plant protection products or fertilizers stored inside;

2) instructions and safety rules including the principles of pesticide and fertilizer storage;

3 ) phone numbers of the nearest emergency call centre or health maintenance organization.

It is necessary to equip the warehouse with flooring which is made of material which is noncombustible, easily washable, slip-reducing and is resistant to shock and corrosive substances.

Storage of plant protection products require specially prepared rooms. Under paragraph $1 \S 10$ the warehouse must contain a separate closed facility that serves to:

1) store plant protection products classified as toxic and very toxic;

2) store defective plant protection products, the products' empty containers, fertilizers or personal protective equipment, contaminated with plant protection products or fertilizers, which are to be decommissioned.

The outside and inside doors of the warehouse must be closed at each entrance and exit. It should be noted that before an employee enters the rooms, the emergency ventilation system is to be turned on for at least five minutes, in spite of the continuous ventilation. In rooms intended for the storage of plant protection products and fertilizers, measurements of temperature and humidity are mandatory. Substances and equipment stored in the warehouse must be kept in their original packaging and grouped according to their use and toxicity. For hygiene reasons, it is forbidden to smoke and to eat in the warehouses and to store there:

1) food and medicines;

2) animal feed;

3 ) seeds and crops not treated with plant protection products;

4 ) personal belongings;

5) propellants and flammable materials.

In addition, it is unacceptable to store ammonium nitrate mixed with other fertilizers.

The farmer is exposed to harmful chemical agents not only while storing and handling plant protection products, but also while treating plant seeds. Therefore, treating seeds with plant protection products must be done mechanically by seed dressers designed for this purpose. They can only be used in ventilated rooms equipped with an emergency ventilation system. Another instance when a farmer can be intoxicated is if there is contact with pretreated seeds. Therefore, it is necessary that until they are sowed, the treated seeds must be stored in:

1) containers that:

a) can be secured permanently and in a way which makes it impossible to open them without damaging the container;

b) are protected against contact with pesticides;

2) separate, sealed and labeled areas.

If the seeds are in hermetically sealed packages up to a net weight of $0.5 \mathrm{~kg}$, they do not require storage in separate, sealed and labeled areas. After performing 
the procedures, it is forbidden to perform other tasks in the areas where the seeds are treated or stored. As it is known, during spraying or fertilizing an equipment failure can occur. This creates a risk for the farmer, because while repairing the breakdown he may come into direct contact with the fertilizer or other substances without having the opportunity to wash thoroughly. Therefore, when working off-site, only ad hoc repairs of the equipment used in the application of plant protection products or fertilizers can be carried out, but only after switching off the equipment. If repairs, inspection or testing of the equipment used in the application of plant protection products or fertilizers in a repair workshop is necessary, then it is mandatory to clean and wash this equipment beforehand. Another of the farmer's duties is to remove the plant protection products or fertilizers from the equipment. The farmer has to load and unload these products in such a way as to avoid any damage to the packaging, as this can result in his direct contact with harmful substances and products. The farmer is also potentially exposed to injurious chemical agents during the transport of plant protection products and fertilizers. Therefore, when these substances are transported from the warehouse to their place of use, they must be protected against atmospheric agents and against dust, general spillage and, in particular, spillage with which employees will come into direct contact. In a case where plant protection products or fertilizers spill or spill out during transport, they shall be removed from the ground, and the contaminated areas must be flushed with water or excavated. In rural areas, farm equipment is used to transport people, therefore, it is unacceptable to transport people, animals, materials and objects on vehicles or

\section{Bibliography}

1. The Act of June 26th, 1974. Labour Code / Journal of Laws.- 1998.- № 21, item. 94 with changes.

2. The Act of December 20th, 1990 on farmers' social security / Journal of Laws.- 2008.- № 50, as amended, item 291.

3. Choroby Zawodowe, red. K. Marek.- Warszawa: Wydawnictwo Lekarskie PZWL, 2001.

4. Higiena Pracy Tom I, Instytut Medycyny Pracy im. prof. dra med.-Lodz: George Nofer, 1999.- 261 p.

5. The Decree of the Minister of Agriculture and Rural Development of January, 12th 1998 on health and safety equipment which are also transporting plant protection products, fertilizers and packages containing these products. After finishing the work related to the use of plant protection products and fertilizers, vehicles or equipment are required to be cleaned and washed at a facility with a sewage treatment plant or a settlement tank to neutralize the resulting wastewater. Even if the farmer observes all the hygiene rules while using plant protection products and fertilizers, poison can enter the body. Therefore, if employees experience symptoms indicating the possibility of poisoning and intoxication, the employer shall be immediately informed; then he must notify the nearest emergency call center or health care establishment.

\section{Conclusions}

Reducing the impact of harmful chemical agents on the health of farmers requires the implementation of a number of preventive measures. As mentioned in the introduction, most farmers perform their activities on an individual basis, thus, farmers are not subject to the full range of safety regulations. Therefore, prevention activities carried out for the last several years by the Agricultural Social Security Fund as a part of its statutory activities are very important. However, it should be noted that these activities require appropriate legislation in the field of farmers' health. As indicated, the regulations mentioned above are adapted to the specificity of different agricultural activities. The health rules concerning plant protection products and fertilizers are those which are the most extensively regulated by Polish legislation. This is fully justified by the direct threat which pesticides present to humans and animals.

when operating tractors, machinery, tools and technical equipment used in agriculture / Journal of Laws.- 1998.№ 12 , item 51 .

6. The Decree of the Minister of Agriculture and Rural Development of September 28th, 2001 on health and safety when handling livestock / Journal of Laws.2001.- № 118, item. 1268, as amended.

7. The Decree of the Minister of Agriculture and Rural Development of 24 June 2002 on health and safety while handling and storage of plant protection products and mineral and organic - mineral fertilizers / Journal of Laws.- 2002.- № 99, item 896, as amended. 


\section{Чапка М., ${ }^{1,2}$, Йохимчик А. ${ }^{3}$ \\ ПРАВОВІ АСПЕКТИ ОХОРОНИ ЗАОРОВ'Я ФЕРМЕРІВ В ПОАЬШ В ПРОЦЕСІ ВИРОБНИЧТВА СИРОВИНИ ААЯ ХАРЧОВИХ ПРОАУКТІВ, ВКАЮЧАЮЧИ ВПАИВ

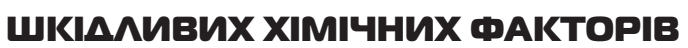

'Верхньосилезька виша педагогічна школа імені КарА. А. Х^ьонда, м. Мисловіче

²Опольский політехнічний університет, м. Ополе

${ }^{3}$ Виша школа економіки та амміністрашії, м. Битом

Фермер під час праці піддається дії ряду факторів, шкідливих для здоров'я. Перш за все, шкідливому впливу хімічних і біологічних факторів, меншою мірою фізичних факторів. Тривалий вплив шкідливих хімічних речовин на організм фермера може призвести до розвитку професійних хвороб. У зв'язку з цим, особлива увага в статті була приділена правовим нормам стосовно захисту здоров'я фермерів від цих чинників, обмежуючись законодавством, безпосередньо пов'язаним з сільськогосподарською працею.

Ключові слова: охорона праці, фермерські професійні захворювання, шкідливі хімічні фактори, законодавство з безпеки та охорони праці

\section{Чапка М.1,2, Йохымчик A. ${ }^{3}$ \\ ПРАВОВЫЕ АСПЕКТЫ ОХРАНЫ ЗАОРОВЬЯ ПОАЬСКИХ ФЕРМЕРОВ В ПРОUЕССЕ ПРОИЗвОАСТВА ПИШЕвОГО СЫРЬЯ, ВКАЮЧАЯ ВОЗАЕЙСТВИЕ ВРЕАНЫХ ХИМИЧЕСКИХ ФАКТОРОВ}

'Верхнесилезский педагогический институт имени Кардинала А. Х^онда, г. Мысловиче

²Опоьский политехнический институт в г. Ополе

ЗИнститут экономики и амминистрашии в г. Бытом

В процессе работы фермер подвергается воздействию ряда факторов, вредных для здоровья. Прежде всего, речь идет о вредном воздействии химических и биологических факторов, и в меньшей мере- физических. Долговременное воздействие вредных химических факторов на организм может приводить к развитию у фермера профессионального заболевания. В связи с этим, в данной статье основное внимание уделяется правовым регулирующим действиям, касающимся защиты здоровья фермеров от этих факторов, с ограничением до правовых норм, непосредственно связанных с работой фермеров.

Ключевые слова: гигиена труда, профессиональные заболевания в сельском хозяйстве, вредные химические факторы, право безопасности и гигиены труда

Надійшла: 10.02 .2013 p.

Контактна особа: Чапка М., Опольский політехнічний університет, м. Ополе. 